\title{
PROTECTIVE ORDERS PROHIBITING DISSEMINATION OF DISCOVERY INFORMATION: THE FIRST AMENDMENT AND GOOD CAUSE
}

Federal Rule of Civil Procedure 26(c) ${ }^{1}$ authorizes courts to order parties to litigation not to disseminate information obtained in civil discovery. ${ }^{2}$ Rule 26 (c) requires a party seeking this type of order to show "good cause" why it should be issued. ${ }^{3}$ The purpose of such protective orders is to restrain the expression of the ordered party. This restraint raises difficult first amendment questions. Few courts have discussed the extent to which the first amendment protects discovery information, or the circumstances in which protective orders prohibiting dissemination are constitutionally permissible. Those courts that have discussed these issues have used inconsistent approaches and have reached radically different results.

Recently the Court of Appeals for the District of Columbia addressed the question extensively in In re Halkin. ${ }^{4}$ Over a sharp dissent, the Halkin court found a first amendment right to disseminate discovery information, and it set forth a three-part test for assessing the constitutionahity of protective orders prohibitimg such dissemination. The Halkin test calls for inquiry whether the dissemination poses a threat of significant harm, whether the protective order is narrowly drawn, and whether less intrusive alternatives exist for protecting parties and the pubhic from dissemination. ${ }^{5}$ Halkin is the first decision to formulate a useful standard for determining whether a protective order is constitutional.

The Halkin decision raises two important issues: first, given the strength of the dissent in Halkin and the inconsistent treatment of the first amendment interest in other courts, the scope of the first amend-

THE FOLLOWING CITATION WILL BE USED IN THIS COMMENT:

8 C. Wright \& A. Miller, Federal Practice and Procedure (1970), hereinafter cited as WRIGHT \& MILLER.

1. FED. R. CIV. P. 26(c). The rule is set out in full at note 19 infra.

2. See notes 26-28 infra and accompanying text.

3. FED. R. CIV. P. 26(c). See notes 29-39 infra and accompanying text.

4. 598 F.2d 176 (D.C. Cir. 1979).

5. The Halkin test is discussed more fully at notes $182-96$ infra and accompanying text. 
ment right to disseminate discovery information is still uncertain. ${ }^{6} \mathrm{Sec}-$ ond, if a party has a constitutional right to disseminate discovery information, the courts must still determine the circumstances, if any, in which protective orders prohibiting dissemination are constitutional. This Cominent analyzes each of these probleins. The purposes of this analysis are to show that sound first amendment interpretation compels recognition of a right to disseminate discovery information, to show that protective orders prohibiting dissemination of discovery information are nevertheless constitutionally permissible under a balancing-ofinterests theory, and to argue that mcorporating the Halkin test into the good cause requirement of Rule 26(c) creates a useful standard for determining whether a protective order prohibiting dissemination may constitutionally be issued.

\section{Protective Orders Prohibiting Dissemination: BACKGROUND}

Civil discovery facilitates hitigation by providing litigants with access to relevant information held by an opposing party. ${ }^{7}$ The scope of discovery is governed by Federal Rule of Civil Procedure 26(b), which provides for discovery "regarding any inatter, not privileged, which is relevant to the subject nuatter involved in the pending action." 8 Gener-

6. See, e.g., 92 HARv. L. Rev. 1550 (1979) (casenote on Halkin criticizing the majority opinion and siding with the dissent on first amendment issues).

7. Before 1938 civil litigation had virtually no discovery process. See WRIGHT \& MiLler $\S 2002$, at 21. The discovery provisions now in Federal Rules of Civil Procedure 26-37 were heralded as a much needed innovation in federal civil procedure. Justice Murphy, in Hickman v. Taylor, 329 U.S. 495 (1947), the seminal decision on the scope of the discovery process, declared:

[T] he deposition-discovery rules are to be accorded a broad and liberal treatment. No longer can the time-honored cry of "fishing expedition" serve to preclude a party from mquirimg into the facts underlying his opponent's case. Mutual knowledge of all the relevant facts gathered by both parties is essential to proper litigation. To that end, either party may compel the other to disgorge whatever facts he has in his possession.

Id. at 507. The Federal Rules permit litigants to obtain substantial amounts of relevant information that otherwise would not be available. This access to relevant information serves numerous purposes, such as avoiding surprise, disclosing fully the nature and scope of the controversy, narrowing and simplifying issues, and assisting parties in preparation for trial. See WrIGHT \& MILLER $\S 2001$, at 17-18. Moreover, the access made available by discovery is not simply access to information already held by the courts, but is instead direct access to information held by an opposing party. When a party resists discovery of information it possesses, rule 37 empowers judges to order production and apply sanctions for refusal to comply. FED. R. CIV. P. 37(a). Thus, discovery is a system of access to information created and regulated by the courts, in which litigating parties are granted liberal access to information held by their opponents in order to facilitate "the fullest possible knowledge of the issues and facts before trial." Hickman v. Taylor, 329 U.S. at 501.

8. FED. R. CIV. P. 26(b)(1) provides:

Parties may obtain discovery regarding any matter, not privileged, which is relevant to the subject matter involved in the pending action, whether it relates to the claim or defense of the party seeking discovery or to the claim or defense of any other party, includ- 
ally, courts construe the discovery rules ${ }^{9}$ to maximize the availability of discovery. ${ }^{10}$

Although the discovery process is designed to work with a minimum of judicial intrusion, ${ }^{11}$ the Federal Rules empower the courts to regulate access to discovery information by four principal methods. First, rule 26(b) limits the scope of discovery to relevant information ${ }^{12}$ that is not privileged. ${ }^{13}$ Second, the rules prescribe the procedures to be followed by participants in the discovery process. ${ }^{14}$ Third, rule 26(c) empowers judges to issue orders to protect parties and witnesses from abuse or undue hardship occasioned by the discovery process. ${ }^{15}$ Fourth, the rules provide for sanctions applicable against parties failing to comply with the other discovery rules. ${ }^{16}$ Information held by an opposing party is accessible only within the limits of the discovery rules. Litigants do not possess a "right" of access to discovery information. ${ }^{17}$

\begin{abstract}
ing the existence, description, nature, custody, condition and location of any books, documents, or other tangible things and the identity and location of persons having knowledge of any discoverable matter. It is not ground for objection that the information sought will be inadmissible at the trial if the information sought appears reasonably calculated to lead to the discovery of admissible evidence.
\end{abstract}

9. FED. R. CIV. P. 26-37.

10. See Schlagenhauf v. Holder, 379 U.S. 104, 114-15 (1964); Hickman v. Taylor, 329 U.S. 495, 507 (1947). See generally Wright \& MILLER $§ 2007$. See also Burns v. Thiokol Chemical Corp., 483 F.2d 300, 304 (5th Cir. 1973).

11. See 4 Moore's Federal Practice If 26.02[5], at 26-72 (2d ed. 1979).

12. FED. R. Clv. P. 26(b)(1) requires that requested information be "relevant to the subject matter involved in the pending action." "Relevancy" is necessarily vague since the Federal Rules do not define the term. See Mallinckrodt Chemical Works v. Goldman Sachs \& Co., 58 F.R.D. 348, 353 (S.D.N.Y. 1973); WRIGHT \& MILLER \& 2008, at 45. The concept of relevancy is interpreted liberally. See Association for Women in Science v. Califano, 566 F.2d 339, 343 (D.C. Cir. 1977); Dunbar v. United States, 502 F.2d 506, 509-10 (5th Cir. 1974). See generally WRIGHT \& MILLER $\S 2008$, at 45. "Relevancy" does have limits, though. When information sought in discovery could have no conceivable bearing on the subject matter of the litigation, discovery is not permitted. See, e.g., Jones v. Metzger Dairies, Inc., 334 F.2d 919, 925 (5th Cir. 1964), cert. denied, 379 U.S. 965 (1965); In re Fontaine, 402 F. Supp. 1219 (E.D.N.Y. 1975); Hawes v. C.E. Cook \& Co., 64 F.R.D. 22 (W.D. Mich. 1974), vacated, 538 F.2d 329 (6th Cir. 1976). See generally WRIGHT \& MILLER $§ \S 2008-09$.

13. If information would be privileged at trial, it is likewise privileged for discovery purposes. See WrIGHT \& MILLER § 2016. See also United States v. Reynolds, 345 U.S. 1, 6 (1953); Southern Ry. v. Lanham, 403 F.2d 1 19, 134 (5th Cir. 1968); Oliver v. Committee for Re-election of the President, 66 F.R.D. 553, 556 (D.D.C. 1975).

14. See FED. R. Civ. P. 27-36.

15. FED. R. CIV. P. 26(c). See note 19 infra.

16. FED. R. CIV. P. 37.

17. In re Halkin, 598 F.2d 176, 190 (D.C. Cir. 1979); see Pell v. Procunier, 417 U.S. 817, 834 (1974) (there is no first amendment right of access to information that is not generally available to the public); Zemel v. Rusk, 381 U.S. 1, 16-17 (1965) ("The right to speak and publish does not carry with it the unrestrained right to gather information").

If a right of access did exist, the rules could not infringe upon that right. The discovery rules were not meant to infringe upon the substantive rights of the parties. See Schlagenhauf v. Holder, 379 U.S. 104 (1964); Sibbach v. Wilson \& Co., 312 U.S. 1 (1941). 
In discovery a party may be requested to produce confidential information. For instance, trade secrets, research data, confidential business information, or other sensitive material not generally available to the public may be requested by an adverse party. If the information is discoverable under rule $26(\mathrm{~b})^{18}$ but the party requested to produce has an interest in mamtaining the confidentiality of the imformation, that party may move for a protective order pursuant to rule 26(c): "Upon a motion by a party or by the person from whom discovery is sought, and for good cause shown, the court . . . may make any order which justice requires to protect a party or person from annoyance, embarrassment, oppression, or undue burden or expense . . .."19

If a party seeks protection from dissemination of confidential information, the court has three alternatives. First, it may deny discovery altogether. This is plainly permitted by the language of rule $26(\mathrm{c}) .20$ This type of protection, lowever, undermines the policy of liberal discovery if the requested information is relevant to the hitigation. Denying discovery protects the one party's confidentiality but deprives his adversary of information useful in the preparation of his case. ${ }^{21}$ Sec-

18. See note 8 supra.

19. FED. R. Civ. P. 26(c) provides in full:

(c) Protective Orders. Upon motion by a party or by the person from whom discovery is sought, and for good cause shown, the court in which the action is pending or alternatively, on matters relating to a deposition, the court in the district where the deposition is to be taken may make any order which justice requires to protect a party or person from annoyance, einbarrassment, oppression, or undue burden or expense, including one or more of the following: (1) that the discovery not be had; (2) that the discovery may be had only on specified terns and conditions, including a designation of the time or place; (3) that the discovery unay be had only by a method of discovery other than that selected by the party seeking discovery; (4) that certain matters not be inquired into, or that the scope of the discovery be limited to certain matters; (5) that discovery be conducted with no one present except persons designated by the court; (6) that a deposition after being sealed be opened only by order of the court; (7) that a trade secret or other confidential research, development, or commercial information not be disclosed or be disclosed only in a designated way; (8) that the parties simultaneously file specified documents or information enclosed in sealed envelopes to be opened as directed by the court.

If the motion for a protective order is denied in whole or in part, the court may, on such terms and conditions as are just, order that any party or person provide or permit discovery. The provisions of Rule 37(a)(4) apply to the award of expenses incurred in relation to the motion.

Although rule 26(c) lists eight types of protective orders, it is well settled that the list is merely illustrative; a court may, im its discretion, fashion any order which justice requires. See WRIGHT \& MILLER $§ 2036$, at 269. This is clear from the text of the rule, which expressly authorizes a court to "make any order . . . including one or more of the following." FED. R. CIv. P. 26(c) (emphasis added).

20. See Fed. R. Civ. P. 26(c)(1) \& (7), set out in full at note 19 supra.

21. Sce Johnson Foils, Inc. v. Huyck, 61 F.R.D. 405 (N.D.N.Y. 1973):

The exercise of the court's discretion must be guided by the liberal federal primciples favoring disclosure, keeping in mind the need to safeguard confidential information transmitted within the discovery process from disclosures harmful to business interests. Both sides should have meaningful access to this type of information . . . where it can be reasonably shown to be "relevant" to the prosecution or defense of a claim. 
ond, the court may compel production without granting a protective order. ${ }^{22}$ Absent any judicial order to the contrary, discovery, like other pretrial proceedings, is "ordinarily to be conducted in public."23 Moreover, in the absence of a protective order, parties may use discovery information as they wish. ${ }^{24}$ Accordingly, when the producing party has a legitimate interest in preserving the confidentiality of the requested information, an order compelling production without a protective order means the producing party must suffer the impact of disclosure or dissemination by the party receiving the information. This result is plainly harsh; the purpose of discovery is effectuated by production alone, ${ }^{25}$ not by dissemination. The court's third option is to compel discovery but to restrict or prohibit dissemination, pursuant to rule 26(c). ${ }^{26}$ A protective order permitting discovery but prohibiting dis-

Id. at 409. See also Hickman v. Taylor, 329 U.S. 495, 501 (1947); Olympic Refining Co. v. Carter, 332 F.2d 260, 265 (9th Cir. 1964).

22. See FED. R. Civ. P. 37(a).

23. Olympic Refining Co. v. Carter, 332 F.2d 260, 264 (9th Cir. 1964); see Davis v. Romney, 55 F.R.D. 337 (E.D. Pa. 1972); Essex Wire Corp. v. Eastern Elec. Sales Co., 48 F.R.D. 308 (E.D. Pa. 1969); $c f$. Publicity in Taking Evidence Act, 15 U.S.C. $\$ 30$ (1976); FED. R. CIv. P. 43(a) (testimony of witnesses must be taken in open court unless a statute or other rule provides otherwise). See generally Hickman v. Taylor, 329 U.S. 495 (1947).

24. See Leonia Amusement Corp. v. Loew's, Inc., 18 F.R.D. 503, 508 (S.D.N.Y. 1955); accord, Essex Wire Corp. v. Eastern Elec. Sales Co., 48 F.R.D. 308, 312 (E.D. Pa. 1969).

25. See note 7 supra. Given the broad scope and liberal application of the discovery rules, parties can use discovery simply to extract confidential information from an opposing party. See 48 U. CIN. L. REv. 900, 909 n.40 (1979). Such extrajudicial use of the discovery process is in effect a judicially enforced invasion of privacy. The discovery rules are meant to aid the litigation process, not to permit general extraction of confidential information. Cf. Hickman v. Taylor, 329 U.S. 495,501 (1947) ("The new rules. . . restrict the pleadings to the task of general notice-giving and invest the deposition-discovery process with a vital role in the preparation for trial. . . . The way is now clear, consistent with recognized privileges, for the parties to obtain the fullest possible knowledge of the issues and facts before trial") (emphasis added).

This is not to say, however, that dissemination may not serve a useful purpose. Dissemination of requested information may contribute to the public understanding of important social affairs. That dissemination does not specifically further the purpose of discovery does not a priori compel prohibitions on dissemination. If discovery information touches upon subjects of general public interest, dissemination may serve a legitimate purpose in informing the public. See, e.g., Howard \& Crowley, Pleading, Discovery, and Pretrial Proeedure for Litigation Against Government Spying, 55 U. Det. J. URB. L. 931 , 962-63 (1978) (dissemination may be a remedy in its own right in cases of official misconduct or deprivation of constitutional rights because exposure may force government officials to stop engaging in unlawful activity). See also 48 U. CIN. L. REv., supra, at 909 n.40 (1979).

Nevertheless, discovery is principally a litigation tool, not a mechanism for forced publication of confidential information. Dissemination of discovery information does not make litigation more efficient, or aid in preparation for trial.

26. In most cases in which a party seeks protection of confidential information, the courts order discovery. "[T]he key issue is not whether the information will be disclosed but under what conditions." WRIGHT \& MILLER $\S 2043$, at 305 . The discussion of this section addresses the role of protective orders prohibiting dissemination of discovery information absent any first amendment considerations. 
semination of the discovery information to third parties satisfies the liberal disclosure pohicies underlying the discovery process. ${ }^{27}$ At the same time, this type of protective order minimizes the harm to the producing party from the release of confidential information. Such an order thus appears to be the best of the available alternatives. Such orders are, in fact, frequently issued by courts to facilitate discovery while protecting confidentiality. 28

Protective orders may be issued only upon a motion by a party or other person from whom discovery is souglit and only if the moving party shows "good cause" why the order should issue. ${ }^{29}$ What constitutes a showing of good cause depends on the type of protection sought and the particular facts of the case. ${ }^{30}$ The decision to grant a protective order is thus left to the sound discretion of the trial judge. ${ }^{31}$ Yet a finding of good cause requires, at a minimum, a clear, specific, factual demonstration that the party seeking protection will incur serious injury in the absence of protection. ${ }^{32}$ Precisely how serious the potential injury must be is unclear, beyond the settled rule that general assertions of confidentiality or conclusory allegations of potential injury are insufficient. ${ }^{33}$ The decisions attempting to set forth the necessary degree of harm range from requiring that "disclosure will work a clearly defined and very serious injury," 34 to requiring a "particular and specific dein-

27. See note 7 supra.

28. E.g., Gentron Corp. v. H.C. Johnson Agencies, Inc., 79 F.R.D. 415 (E.D. Wis. 1978); Haykel v. G.F.L. Furniture Leasing Co., 76 F.R.D. 386 (N.D. Ga. 1976); Vollert v. Summa Corp., 389 F. Supp. 1348 (D. Hawaii 1975); Essex Wire Corp. v. Eastern Elec. Sales Co., 48 F.R.D. 308 (E.D. Pa. 1969); Nichols v. Philadelphia Tribune Co., 22 F.R.D. 89 (E.D. Pa. 1958). See also Federal Open Mkt. Comm. v. Merrill, 443 U.S. 340, 362 n.24 (1979), and cases cited therem. The Merrill case is discussed in Comment, Developments Under the Freedom of Information Act1979, 1980 DUKe L.J. 139, 155-59.

29. FED. R. Civ. P. 26(c). The burden is on the party seeking the order to show good cause. Kiblen v. Retail Credit Co., 76 F.R.D. 402 (E.D. Wash. 1977); United States v. IBM, 66 F.R.D. 186, 189 (S.D.N.Y. 1974); Essex Wire Corp. v. Eastern Elec. Sales Co., 48 F.R.D. 308, 310 (E.D. Pa. 1969). See WRIGHT \& Miller $\$ 2036$.

30. See Glick v. McKesson \& Robbins, Inc., 10 F.R.D. 477, 479 (W.D. Mo. 1950); WRIGHT \& MILLER § 2035, at 266.

31. See Chemical \& Indus. Corp. v. Druffel, 301 F.2d 126 (6th Cir. 1962); Aluminum Co. of America v. United States Dep't of Justice, 444 F. Supp. 1342, 1346-47 (D.D.C. 1978); Essex Wire Corp. v. Eastern Elec. Sales Co., 48 F.R.D. 308, 310 (E.D. Pa. 1969).

32. See General Dynamics Corp. v. Selb Mfg. Co., 48I F.2d 1204 (8th Cir. 1973), cert. denied, 414 U.S. 1162 (1974); United States v. IBM, 67 F.R.D. 40 (S.D.N.Y. 1975); Apco Oil Corp. v. Certified Transp. Co., 46 F.R.D. 428 (W.D. Mo. 1969); WRIGHT \& Miller $§ 2035$, at 265.

33. E.g., Rosenblatt v. Northwest Airlimes, Inc., 54 F.R.D. 21 (S.D.N.Y. 1971); Technical Tape Corp. v. Minnesota Mining \& Mfg. Co., 18 F.R.D. 318 (S.D.N.Y. 1955); see WRIGHT \& MILLER $\$ 2035$, at 265 , and $\$ 2043$, at 301 .

34. United States v. IBM, 67 F.R.D. 40, 46 (S.D.N.Y. 1975) (emphasis in original). 
onstration of fact,"35 or even "that the party disclosing will indeed be harmed by disclosure."36

A series of other factors must be weighed agamst the harm of dissemination to determine whether there is good cause for an antidissemination protective order. These countervailing considerations include the policy that discovery should take place in public, ${ }^{37}$ the hardship that a protective order would impose on the party seeking discovery, ${ }^{38}$ and the extent to which the information sought to be protected is truly confidential. ${ }^{39}$ This balancing process has not produced a general standard of good cause, except for the requireinent of a specific showing of harm. One additional, yet seldom recognized, factor that a court determining the propriety of a protective order inust consider is the first alnendinent interest of the party requesting the inforination.

\section{Protective Orders as Restraints on Expression}

Protective orders restricting dissemination of discovery information are important tools for regulating the discovery process. Such orders protect the interests of the producing party, while providing the requesting party with access to discoverable information. By prohibiting dissemination or disclosure of the discovery information, however, protective orders operate as a restraint on the requesting party's freedoin of expression and thereby implicate first amendment considerations.

Antidissemination protective orders are similar to judicial orders restraming the press, the public, the parties, or attorneys from dissemi-

35. General Dynamics Corp. v. Selb Mfg. Co., 481 F.2d 1204, 1212 (8th Cir. 1973), cert. denied, 414 U.S. 1162 (1974). See also WRIGHT \& MILLER \& 2035, at 265.

36. Johnson Foils, Inc. v. Huyck Corp., 61 F.R.D. 405, 409 (N.D.N.Y. 1973). See also Essex Wire Corp. v. Eastern Elec. Sales Co., 48 F.R.D. 308 (E.D. Pa. 1969).

37. See United States v. IBM, 66 F.R.D. 219 (S.D.N.Y. 1974); Johnson Foils, Inc. v. Huyck Corp., 61 F.R.D. 405 (N.D.N.Y. 1973). See generally Olympic Refining Co. v. Carter, 332 F.2d 260, 265 (9th Cir. 1964).

38. See General Dynamics Corp. v. Selb Mfg. Co., 481 F.2d 1204, 1212 (8th Cir. 1973), cert. denied, 414 U.S. 1162 (1974). General Dynamics does not clearly explain what hardships an order prohibiting dissemmation would cause. If a party has a first amendment right to disseminate discovery information, an order proscribing dissemination presumably results in hardship by abrogating that right. See text accompanying notes 102-11 infra. The General Dynamics court, however, did not discuss first annendment considerations.

39. To determine whether information was truly confidential, the court in Reliance Ins. Co. v. Barron's, 428 F. Supp. 200 (S.D.N.Y. 1977), considered the extent to which the information was known outside of the business, the extent to which it was known inside the business, the measures taken to guard the secrecy of the information, and the value of the information to the business and its competitors. $I d$. at 203-04. 
nating infornation obtained in judicial proceedings. ${ }^{40}$ Judicial orders restraining extrajudicial comment im contexts other than discovery are uniformly scrutinized under the first amendment. ${ }^{41}$ Most of the courts that have issued protective orders prohibiting or restricting dissemination of discovery information, however, have not addressed the first amendinent implications of those orders. ${ }^{42}$ Those cases that have confronted the first amendment problem have employed conflicting theories and have obtamed inconsistent results.

\section{A. The Pre-Halkin Cases: Conflicting Approaches.}

One line of cases treats protective orders restricting dissemination of discovery information as meriting hittle, if any, first amendinent scrutiny. These cases consider information obtained through discovery as analytically distinct from information acquired outsidc of the discovery process. In International Products Corp. v. Koons, ${ }^{43}$ the Court of Appeals for the Second Circuit considered the validity of a protective order that both sealed a deposition and prohibited dissemination of certain information obtained outside of discovery proceedings. The subject matter of the deposition and the independently acquired inforination both concerned payinents by corporate officers to South American government officials. The protective order issued by the district court prohibited dissernination of any information concerning these payments, thus encompassing the information acquired independently as well as the contents of the deposition. ${ }^{44}$ The district court had determined that public dissemination of the material would be "extremely embarrassing" to the deponent and "contrary to the best interests of the foreign policy of the Uinted States." 45 The restricted party challenged the order, claiming deprivation of its first amendinent rights.

The Second Circuit divided the order into two components: that portion pertaining to information obtained by deposition, and that portion imvolving information independently acquired. Any restriction upon the right to disseminate the latter was held unconstitutional:

40. See text accompanying notes 112-34 infra.

41. See text accompanying notes $112-33$ infra. See also Comment, Restrictions on Communication By Class Action Parties and Attorneys, 1980 Duke L.J. 360, 370-84 (orders restricting communications by parties and attorneys in the class action context should be scrutinized under the first amendment).

42. See, e.g., General Dynamics Corp. v. Selb Mfg. Co., 481 F.2d 1204 (8th Cir. 1973), cert. denied, 414 U.S. 1162 (1974); Haykel v. G.F.L. Furniture Leasing Co., 76 F.R.D. 386 (N.D. Ga. 1976); United States v. IBM, 67 F.R.D. 40 (S.D.N.Y. 1975); Essex Wire Corp. v. Eastern Elec. Sales Co., 48 F.R.D. 308 (E.D. Pa. 1969).

43. 325 F.2d 403 (2d Cir. 1963).

44. Id. at 404.

45. Id. at 405 . 
What causes concern here is that the order . . curtailed disclosure of information and writings . . possessed [before the deposition was taken]. We fail to see how the use of such documents or information im argumg motions can justify an order preventing [the restricted parties] from exercising their First Amendment rights to disclose such documents and information free of governinental restraimt. ${ }^{46}$

The court firmly rejected, however, the first amendment claim as applied agamst the court-sanctioned discovery information:

The portion of the order which seals the deposition ... and limits ... [the use] of information obtained therefrom was plainly authorized by F.R. Civ. Pro. 30(b), and we entertam no doubt as to the constitutionahity of a rule allowing a fcderal court to forbid the publicizing, in advance of trial, of information obtamed by one party from another by use of the Court's processes. ${ }^{47}$

The court viewed a protective order governing use of discovery material as an exercise of its "inherent equitable powers [over its own processes] to prevent abuses, oppression, and injustices," 48 and found no doubt "as to the propriety of the exercise of discretion here." 49 In assessing the constitutionahity of the order prohibiting dissemnination, the Koons court thus distinguished discovery information from independently acquired information. Although the grounds for the protective order were identical for each kind of information, prohibiting dissemination of independently acquired information was held constitutionally impermissible, while prohibiting dissemination of discovery information was allowed.

More recently, the Court of Appeals for the Third Circuit analyzed this problem in Rodgers $v$. United States Steel Corp. ${ }^{50}$ In Rodgers, the district court had issued a protective order prohibiting disclosure by counsel of the contents of a deposition and of a inemorandum obtained by counsel outside of discovery channels. ${ }^{51}$ The

46. Id. at 408 .

47. Id. at 407 . The protective order provisions presently contained in rule $26(\mathrm{c})$ were, prior to 1970 , set forth in rule 30 (b). In addition, the 1970 revisions changed the language to make protective orders applicable to all forms of discovery. See Notes of Advisory Committee on 1970 Amendment to Rules, 28 U.S.C. app. 440, 444 (1976).

48. 325 F.2d at $407-408$ (quoting Gumbel v. Pitken, 124 U.S. 131, 144 (1888)). In Parker v. CBS, 320 F.2d 937 (2d Cir. 1963), the Second Circuit addressed a similar situation. The plaintiff submitted a memorandum in support of a judgment on the pleadings. At the defendant's request, the plaimtiff was ordered not to disseninate either the memorandum or information contained in it. The court upheld the order insofar as it applied to the memorandum but indicated that the portion of the order pertaining to the information contained in the memorandum was repugnant to the first amendment. Id. at 939 .

49. 325 F.2d at 408.

50. 536 F.2d 1001 (3d Cir. 1976).

51. The case arose out of an attempt to settle a Title VII claim against United States Steel. The deposition of a Justice Department attorney included testimony about the formula used to 
court of appeals vacated the protective order on first amendment grounds, insofar as it prohibited dissemination of the independently acquired memorandum. ${ }^{52}$ The court concluded, however, that its decision did not apply to that portion of the order restricting dissemination of the contents of the deposition. The court assumed that if the order had been limited to discovery material, it would have been valid:

[W] need not and do not consider here whether a protective order which prohibits parties or their counsel from disclosing information or matters obtained solely as a result of the discovery process is ever subject to the First Amendment's prohibitions against the establishment of laws that abridge freedom of speech. It inay well be, for instance, that the parties and counsel, by taking advantage of or a part in the discovery processes, implicitly waive their First Amendment rights freely to disclose or disseminate the information obtained through those processes. ${ }^{53}$

This language reaffirms the Koons distinction between restricting dissemination of discovery materials on the one hand and independently acquired information on the other. Moreover, the court raised the possibility that a party, by participating in the discovery process, waives its first amendment right to disseminate. Thus, Rodgers goes one step beyond Koons by questioning whether a first amendment right to disseminate discovery information ever exists.

In contrast to Koons and Rodgers another line of cases treats protective orders prohibiting dissemination of discovery information as nearly equivalent to prior restramts on expression, which bear a heavy presumption of unconstitutionality. ${ }^{54}$ In Davis $v$. Romneys5 the plaintiffs sought discovery of government documents in an action alleging substandard conditions in hoines insured by the Federal Housing Administration. The defendants initially neglected to produce the requested documents. Faced with an order compelling discovery, however, they sought a protective order either denying discovery or keeping the information off the public record, to "prevent its being available to the local press." 56 In their motion for a protective order,

calculate a back-pay award. Petitioners, however, independently acquired a docunent containing essentially the same information. The district judge prohibited dissemination of both items. Id. at 1005 n.8.

52. Id. at 1009 .

53. Id. at 1006 (dictum).

54. Under the first amendment a prior restraint on expression bears a "heavy presumption" of invalidity. See, e.g., Southeastern Proinotions Ltd. v. Conrad, 420 U.S. 546, 558 (1975); New York Times Co. v. United States, 403 U.S. 713, 714 (1971); Organization for a Better Austin v. Keefe, 402 U.S. 415,419 (1971); Carroll v. Princess Anne, 393 U.S. 175, 181 (1968); Bantam Books v. Sullivan, 372 U.S. 58, 70 (1963); Near v. Minnesota, 283 U.S. 697 (1931).

55. 55 F.R.D. 337 (E.D. Pa. 1972).

56. Id. at $339-40$. 
the defendants alleged that dissemination would create two potential harms: first, public dissemination of the mformation would create an atmospliere $\mathrm{m}$ which persons tried in related criminal proceedings ${ }^{57}$ might not receive a fair trial; and second, public disclosure would invade the privacy of certain persons named in the requested documents. Rejecting both arguments, the district court found the requested protective order very similar to a prior restraint on expression..$^{58}$ The court perceived the order as a restraint on the press, and concluded that neitler the potential denial of a fair trial because of adverse publicity nor the possible invasion of privacy justified the order: "By suggesting only possible difficulties that could result from allowing the press access to the information through the public record, the defendants have not sustained the heavy burden required for a prior rcstraint." 59 The court failed to consider that the requested order applied only to discovery information; its analysis of the first amendment problen1 is thus different from the approach in Koons and Rodgers. 60 By not addressing the issue, Davis implicitly rejected the notion that information acquired in discovery and information independently acquired require separate treatment under the first amendinent.

In Reliance Insurance Co. v. Barron's, ${ }^{61}$ a 1977 case involving securities and libel claims, ${ }^{62}$ the district court applied a similar prior restraint analysis. In Reliance the plaintiff expressed a willingness to produce certain internal corporate documents and records, but requested a protective order prohibitimg defendants, a magazine and a journalist, froun disseminating the material to anyone other than the parties, their attorneys, or expert witnesses. The plaintiffs also desired to prevent the use of the material "in any publication, address, lecture or otler inedium of public dissemmation, except as such information is a matter of public record or is otherwise known to the defendants and their einployees and agents." 63 The court first decided that the plaintiffs failed to deinonstrate the requisite good cause under Federal Rule 26(c) because the notion lacked a sufficient showing of confidentiality

57. Id. at 343 . The requested documents were pertinent to grand jury proceedings taking place concurrently with the civil action. See id. at 340-43.

58. "While this is not . . . the classic case of a prior restraint, it approaehes it." Id. at 344 (quoting Philadelphia Newspapers, Inc. v. Department of Hous. \& Urban Dev., 343 F. Supp. 1176 (E.D. Pa. 1972)).

59. 55 F.R.D. at 345 (emphasis in original).

60. Davis never refers to the Koons case, decided almost nine years earlier.

61. 428 F. Supp. 200 (S.D.N.Y. 1977).

62. Reliance sued Barron's after the latter published an uncomplimentary article that allegedly impaired the marketability of a proposed stock issue. Id. at 201 .

63. Id. at 202. 
and expected harm from dissemination. ${ }^{64} \mathrm{Had}$ there been no first amendment problem, the court indicated that it would have inspected the material im camera and reconsidered the order. ${ }^{65}$ Instead, the court denied the motion for the protective order outright as an unconstitutional prior restraint on the press. ${ }^{66}$

The Reliance court stated that, under the reasoning in Koons, a protective order is constitutional if the party seeking protection satisfies the "heavy burden of showing justification for the imposition of such a restraint." 67 The court reasoned that a protective order, like any other prior restraint on free expression, carries a heavy burden of justification under the first amendment. Reliance thereby implicitly rejected the Rodgers dictum that a party engaged in discovery waives its first amendment rights. ${ }^{68}$ Accordingly, the order was denied in Reliance because the plaintiff had failed to meet its first amendment burden of showing that "the material to be restrained is, indeed, confidential, and that its publication would cause plaintiff to suffer serious and irreparable injury."69 As in Davis, the Reliance court considered the requested protective order to be tantamount to an order enjoining publication directly. ${ }^{70}$ The Reliance court did not differentiate between orders - prohibiting dissemination of discovery information and similar orders pertaining to independently acquired information.

Koons, Rodgers, Davis, and Reliance present conflicting and irreconcilable approaches to scrutiny of protective orders under the first amendment. Moreover, none of the opimions, except for the dictuin in Rodgers, squarely address the extent of the first amendment interest in disserninating discovery information. Koons sidestepped the issue by assuming that a protective order is valid as applied to discovery information. The court offered no reasons for differentiating between dis-

64. Id. at 204.

65. Id.

66. Id. at 204-05.

67. "[A] prior restraint may be constitutional, under International Products [v. Koons], . . . but one seeking sucl relief bears a 'leavy burden of showing justification for the imposition of suclı a restraint'." Id. at 204 (quoting Organization for a Better Austm v. Keefe, 402 U.S. 415,419 (1971)). The court misread Koons, lowever. If the order in Koons had satisfied the heavy burden required to justify a restraint on expression, then the entire order would have been valid. The differential treatment of discovery material in Koons strongly indicates that the Koons court believed a much lesser burden justifies protective orders than the burden required for restramts on dissemination of independently acquired material. See text accompanying notes 43-49 supra.

68. See text accompanying note 53 supra.

69. $428 \mathrm{~F}$. Supp. at 204 (emplrasis in original).

70. The court may, however, have felt compelled to reach tlis conclusion because the defendants were a magazine and a journalist. Id. at 201. It is unclear whether the Reliance court would liave applied the saine analysis if the restricted parties had not been inembers of the public media. See 92 Harv. L. Rev., supra note 6, at 1553 n.32. 
covery information and independently acquired information. Davis and Reliance equated protective orders prohibiting parties from disseminatimg discovery imformation with direct prior restraints on the press, without providing a sound explanation for the conclusion. None of these cases explicitly set fortl a usable standard or test for assessing the validity of protective orders prohibiting dissemination.

\section{B. The Halkin Decision.}

The extent of a first amendment right to dissemmate discovery information and the circumstances in which that right may be limited received an exhaustive analysis in In re Halkin, ${ }^{71}$ a 1979 decision by the Court of Appeals for the District of Columbia. The plaintiffs in Halkin, a number of individuals and organizations, sued the Central Intelligence Agency, the National Security Agency, and certain other government agencies, alleging illegal surveillance of the plaintiffs and otlier citizens opposed to the war in Vietnam and demanding equitable relief and damages. Pursuant to a request by the plaintiffs under rule 34,72 the defendants produced documents without seeking a protective order. Subsequently, the plaintiffs' counsel notified the defendants of his intention to inake the material available for inspection by the press and the public. The defendants then requested and were granted a protective order prohibiting the proposed dissemination on the ground that public disclosure of the inaterial would be "prejudicial to the defendants' right to adjudication of the issues in this civil action in an uncolored and unbiased climate, including a fair trial." 73 On a petition

71. 598 F.2d 176 (D.C. Cir. 1979).

72. FED. R. Civ. P. 34(a) provides in part: "Any party may serve on any other party a request (l) to produce and permit the party making the request, or someone acting on his behalf to inspect and copy, any designated documents ...."

73. 598 F.2d at 181-82. In support of their position, the defendants cited Local Rule 1-27(d). That rule prohibits attorneys from making extrajudicial comments concerning ongoing litigation, other than references to public records, if it is reasonable to assume that the statement will be publicly disseminated and that the dissemination will interfere with a fair trial. $598 \mathrm{~F} .2 \mathrm{~d}$ at 181 n.5. The defendants also noted that Canon 20 of the ABA Canons of Professional Ethics condemns dissemination of information to newspapers by attorneys regarding pending or anticipated litigation as a potential interference with a fair trial. 598 F.2d at 181 n.5. The District of Columbia Court of Appeals retained Canon 20 "in lieu" of Disciplinary Rules 7-107(G) and (H) of the American Bar Association's Code of Professional Responsibility. Id. Cf. Clicago Council of Lawyers v. Bauer, 522 F.2d 242 (7th Cir. 1975), cert. denied, 427 U.S. 912 (1976) (holding Disciplinary Rule 7-107(G) of the American Bar Association's Code of Professional Responsibility unconstitutional under the first amendment). See notes 128-33 infro and accompanying text. The defendants in Halkin did not, however, submit affidavits or other material in support of the motion for a protective order. 598 F.2d at 182. The district court's order stated, in part:

[I]t appearing to the Court that extra-judicial statements or disclosure of discovery materials by the parties, their counsel, and researchers, consultants, or other persons who may be associated with thein in this civil action are contrary to rules applicable to the 
for a writ of mandamus to vacate the protective order, ${ }^{74}$ the court of appeals held the order invalid as an unconstitutional infringement of the plaintiffs' first amendment rights. ${ }^{75}$

Judge Bazelon's majority opinion contains a thorough examination of the first amendment issues involved in issuing protective orders restricting dissemination of discovery materials. The court initially decided that a protective order prohibiting dissemination is not a paradigmatic prior restramt. ${ }^{76}$ Judge Bazelon noted that "[a] judicial order pursuant to rule 26(c) limiting lawyers' and parties' expression does possess many of the characteristics of an administrative licensing scheme." 77 After surveying the dangers of administrative censorship systems and broad judicial gag orders, ${ }^{78}$ however, he concluded that a protective order differs from a typical prior restraint "because the order can be limited to specific expression rather than imposing a restraint of unknown breadth on speech."79 Thus, the disputed protective order did not bear the "almost insurmountable presumption" of invalidity that confronts a prior restraint. ${ }^{80}$ Nevertheless, the order was sufficiently similar to a prior restramt to require "close scrutiny of its impact on protected First Amendment expression." 81

conduct of litigation before this Court and inconsistent with the obligations of parties and their counsel to further the just determination of matters within its jurisdiction, it is ...

ORDERED that documents and information furnished during the course of discovery in this civil action shall not, unless made a part of the open Court record herein, be the subject, either directly or indirectly, of extrajudicial statements or publication by the parties or their counsel, nor shall they otherwise disclose any such information or documents except in proceedings before this Court ... .

Id. at 182 n.8.

74. The remedy of mandamus is traditionally a "drastic one, to be invoked only in extraordinary situations." Kerr v. United States Dist. Court, 426 U.S. 394, 402 (1976). The Halkin court, upon finding that the protective order violated the plaintiffs' constitutional rights, decided that mandamus was appropriate. 598 F.2d at 197-200. Judge Bazelon's analysis relies heavily on the importance and timeliness of first amendment rights. It is therefore questionable whether the district court's protective order could have been appealed on nonconstitutional grounds. See Rodgers v. United States Steel Corp., 536 F.2d 1001, 1006 n.12 (3d Cir. 1976) (in determining whether to vacate an order prohibiting dissemination of certain information, the court noted: "We are mindful that we should not decide constitutional issues if there is another ground for decision. . . . We reach the First Amendment issue here because if the court's order were constitutional, we doubt that mandamus would be proper in this case to vacate the order").

75. $598 \mathrm{~F}, 2 \mathrm{~d}$ at 197 . The court technically did not issue a writ of mandamus vacating the order. Instead, a copy of the decision was transmitted to the district court "to permit further proceedings in light of the discussion herein." Id. at 200 (footnote omitted).

76. Id. at 183-86.

77. Id. at 183 .

78. $r d$. at 184 n.15.

79. $I d$. at 185 n.17.

80. Id. at 186. See note 54 supra.

81. 598 F.2d at 186. 
- The Halkin court asserted that orders restraining extrajudicial comment by attorneys or parties "have been uniformly held a serious restriction of fundamental First Amendment rights." 82 Noting that "[1]itigation itself is a form of expression protected by the First Amendment," 83 the court concluded that the parties and attorneys could retain their freedom of speech. ${ }^{84}$ Moreover, Judge Bazelon found a general first amendment right to dissemmate information, regardless of how the imformation is acquired. ${ }^{85}$ This right, he reasoned, precludes any himitation upon first amendment rights merely because the imformation is acquired through the discovery process. ${ }^{86}$

Judge Bazelon read Koons narrowly to mean, "[a]t most, . . . that a properly drawn restraining order, supported by a proper showing of good cause, is compatible with the First Amendment." ${ }^{27}$ The court rejected the argument that judicial control over access to discovery information concomitantly empowers a court to condition access and use of discovery information without regard for the first amendment. The court expressly rejected the dictum in Rodgers asserting that litigants waive their first amendment rights by engaging in discovery. 88 Conceding that parties have no right of access to discovery information, Judge Bazelon nevertheless stated that "a court cannot condition the 'privilege' of access on a waiver of First Amendment rights." 89

82. Id. at 187. See, e.g., Chicago Council of Lawyers v. Bauer, 522 F.2d 242 (7th Cir. 1975), cert. denied, 427 U.S. 912 (1976); CBS, Inc. v. Young, 522 F.2d 234 (6th Cir. 1975); Chase v. Robson, 435 F.2d 1059 (7th Cir. 1970). See notes 123-33 infra and accompanying text.

83. 598 F.2d at 187. As authority for this proposition, the court cited In re Primus, 436 U.S. 412,431 (1978) (litigation may be "a vehicle for effective political expression and association, as well as a means of communicating useful information to the public"); NAACP v. Button, 371 U.S. 415,429 (1963) (litigation is "a form of political expression"); and Chicago Council of Lawyers v. Bauer, 522 F.2d at 258 ("Civil litigation in general often exposes the need for governmental action or correction. Such revelations should not be kept from the public").

84. 598 F.2d at 187 .

85. Id. at $187-88$. Judge Bazelon pointed out that courts have recognized a right to disseminate even when the information is stolen (see New York Times Co. v. United States, 403 U.S. 713 (1971)), or taken in violation of a security agreement (see United States v. Marchetti, 466 F.2d 1309 (4th Cir.), cert. denied, 409 U.S. 1063 (1972)). 598 F.2d at 187-88. See also Rodgers v. United States Steel Corp., 536 F.2d 1001, 1008 n.16 (3d Cir. 1976).

86. "A party's right to disseminate information is far stronger for discovery materials than for information that has been stolen or obtained in breach of contract." 598 F.2d at 188. See note 85 supra. Moreover, in the absence of bad faith or a protective order, a party may use discovery information "in any way the law permits." Leonia Amusement Corp. v. Loew's, Inc., 18 F.R.D. 503, 508 (S.D.N.Y. 1955); accord, Essex Wire Corp. v. Eastern Elec. Sales Co., 48 F.R.D. 308, 312 (E.D. Pa. 1969). The federal rules do not restrict the use of discovery materials unless good cause is shown why a restriction should be issued. See In re Halkin, 598 F.2d at 188; FED. R. Civ. P. 26(c).

87. 598 F.2d at 189 (footnote omitted). See note 67 supra.

88. See text accompanying note 53 supra.

89. 598 F.2d at 190. The court embraced the doctrine of "unconstitutional conditions" to 
The Halkin court sought to protect the first amendment interest in disseminating discovery material by fashioning a three-part standard, which it incorporated into the good cause requirement of rule 26(c). This standard represents the first attempt by any court to set forth a pragmatic test for assessing the vahdity of a protective order that prohibits dissemination. The court declared that to justify such a protective order, "the harm posed by dissemination unust be substantial and serious; the restraining order must be narrowly drawn and precise; and there must be no alternative means of protecting the pubhc interest which imtrudes less directly on expression."90 The order issued in Halkin failed on all three counts. First, the allegation that dissemination would threaten defendants' chances for a fair trial was too conclusory to justify protection. Second, the order was overbroad, applying to a large amount of material unexamined by the court. Third, the defendants made no showing that the alleged harm could not be avoided by the use of less intrusive ineans. ${ }^{91}$

Judge Wilkey filed a vigorous dissent. Relying heavily on Koons and Rodgers, he distinguished between orders restricting dissemination of independently acquired information and protective orders directed at discovery materials:

The distinction is this: Although each is a form of "prior restraint," the constitutional permissibility of the first order is determined by application of a vigorous "clear-and-present-danger" type standard, whereas the constitutional permissibility of the latter order is governed by the less stringent standards embodied in the discovery laws. ${ }^{92}$

This difference, argued Judge Wilkey, arises from the difference in the methods of acquiring the information:

[L]itigants who wish to disseminate discovery materials have gained access to such materials-access which they would not ordinarily have-through a statutory system that expressly reserves to the courts the power to attach restrictions on the use of such materials. Thus, when litigants receive discovery materials, they receive them already subject to the courts' exercise of this discretionary power. The First Amendment interest of litigants in the dissemination of this

support its position. See notes $135-51$ infra and accompanying text for a discussion of the doctrine in this context.

90. 598 F.2d at 191 (footnotes omitted). The Halkin test is discussed in the text accompanying notes $178-96$ infra.

91. 598 F.2d at $196-97$.

92. Id. at 204 (Wilkey, J., dissenting). Judge Wilkey further argued that the cases that invalidated judicial orders prohibiting dissemination of independently acquired information-e.g.. Nebraska Press Ass'n v. Stuart, 427 U.S. 539 (1976); Chicago Council of Lawyers v. Bauer, 522 F.2d 242 (7th Cir. 1975), cert. denied, 427 U.S. 912 (1976); CBS, Inc. v. Young, 522 F.2d 234 (6th Cir. 1975); Chase v. Robson, 435 F.2d 1059 (7th Cir. 1970)-were mapposite because the protective order was addressed only to immediate parties and counsel, was himited in duration, and was concerned only with information obtamed in discovery. 598 F.2d at 203-04 (Wilkey, J., dissenting). 
material is, therefore, limited: It is necessarily qualified or conditioned by the potential restrictions that are part of the system through which the materials liave been obtained. ${ }^{93}$

Judge Wilkey further noted that applying a rigorous first amendment test would be illogical: such a test makes it inore difficult to restrict the use of discovery information than to deny discovery altogether. Since no constitutional right of access to discovery material can be asserted, ${ }^{94}$ an order denying discovery does not implicate first amendment interests. The court need only weigh the asserted harm in disclosure against the need for disclosure..$^{95}$ A rigorous constitutional standard for protective orders that compel production but restrict dissemination, according to Judge Wilkey, would be a logical anoinaly that fails to conform with "the principle that the greater (the power to prohibit altogether) includes the lesser (the power to grant with conditions), a bit of logic which has been recognized as vahd at least since the ancient Greeks."96 Therefore, he argued, protective orders restricting dissemination of discovery materials need only satisfy the traditional good cause requirement under rule 26(c). ${ }^{97}$ This showing of good cause is less stringent than the first amendment standards delineated by the Halkin majority and by the courts considering other kinds of judicial orders restraining expression. ${ }^{98}$ Judge Wilkey concluded that the protective order in Halkin had been properly granted by the district court. The already

93. 598 F.2d at 206 (Wilkey, J., dissenting). Judge Wilkey stated that conditioning access to discovery materials was proper:

My view that a recipient of discovery materials has no more than a conditional interest im those materials is thus very analogous to the view taken by Mr. Justice Rehnquist in Arnett v. Kennedy [416 U.S. 134, 155 (1974)] with respect to one's property interest in a government job. Therein Mr. Justice Rehnquist concluded that the property interest which appellee had in his [nonprobationary federal] employment was itself conditioned by the procedural limitations which had accompanied the grant of that interest.

Id. at 207 (Wilkey, J., dissenting) (footnote omitted). But of. id. at 190 n.28 (Bazelon, J., remarking that a majority of the Arnett Court did not accept Justice Rehnquist's argument). The Halkin court rejected the conditional access theory. See text accompanying note 89 supra. For a discussion of the unconstitutional conditions doctrine in this context, see text accompanying notes 135-51 infra.

94. See note 17 supra and accompanying text.

95. See Notes of Advisory Committee, supra note 47, at 444 . Cf. In re Halkin, 598 F.2d at 195 (majority opinion) (if an order denying discovery is the only alternative to an order prohibiting dissemination, the latter order may be the least intrusive alternative).

96. 598 F.2d at 209 (Wilkey, J., dissenting).

97. See text accompanying notes 29-39 supra. In this regard, Judge Wilkey stated that good cause required a showing of reasonable likelihood that the threatened harm would occur. 598 F.2d at 206 (Wilkey, J., dissenting).

98. See note 92 supra. Thus, the predicted harm from dissemination can be "[l]css crippling" than the degree of harm required by the majority in Halkin. 598 F.2d at 206 (Wilkey, J., dissenting). Additionally, Judge Wilkey would leave it to the trial judge's discretion whether to issue a protective order. The court would not be required to make detailed factual findings, but merely to "provide a record sufficient for meaningful review." Id. (Wilkey, J., dissenting); $c f$. Nebraska 
"massive" pretrial publicity surrounding the case, the "selective" release of the materials proposed by plamtiffs, and the judicial policy against extrajudicial comments concerning pending litigation were sufficient to justify a finding that protection was warranted to preserve the chance of a fair trial.99

The Halkin majority and dissenting opinions constitute the nost comprehensive analysis of the extent to which protective orders prohibiting dissemmation of discovery information are permissible under the first ainendinent. But the sharp doctrmal differences represented by the two positions indicate that the problem remains unsettled. The differing views of the Halkin majority, the Wilkey dissent, and the preHalkin cases can be reconciled by a reformulation of the rule 26(c) "good cause" requirement. Such a reformulation can permit a balancing of the legitimate interests of the party seeking protection and the party seeking discovery, while preserving the liberal discovery process.

\section{UnConstitutional Conditions and Conditional ACCess: \\ A FRAMEWORK FOR RECONCILIATION}

The decisions urging separate, less strimgent treatinent of antidissemination protective orders under the first amendinent are grounded in the concept of conditional access: because the court has discretion to deny access to discovery material altogether, it should be able to restrict the use of the material by the recipient. ${ }^{100}$ Although this position has strong logical appeal, ${ }^{101}$ a more thorough analysis reveals that it is unsound.

\section{A. The First Amendment Right to Disseminate Discovery Information.}

Judge Bazelon's conclusion in Halkin that there exists a first amendment right to dissemmate discovery imformation ${ }^{102}$ is well reasoned. The federal rules einbody a policy that, in the absence of judicially imposed restraints, discovery, like other civil pretrial proceedings, is a public proceeding. ${ }^{103}$ If not restricted by a protective order, parties are free to disseminate discovery information. ${ }^{104}$

Press Ass'n v. Stuart, 427 U.S. 539, 563-65 (1976) (requiring detailed findings that less intrusive alternatives are inadequate before issuing an order restraining expression).

99. 598 F.2d at 211-13 (Wilkey, J., dissenting).

100. See text accompanying notes $47,53, \& 93$ supra.

101. See text accompanying note 96 supra.

102. See notes 85-86 supra and accompanying text.

103. See note 23 supra and accompanying text.

104. See note 86 supra. 
Moreover, first amendment protection should not be precluded merely because information has been obtamed through discovery. The courts have consistently recognized a first amendment right to disseminate information without regard to the means by which the information was acquired. This proposition is most clearly exemplified in New York Times Co. v. United States, ${ }^{105}$ in which the Supreme Court refused to enjoin publication of the Pentagon Papers. The majority opinions did not address the fact that the information sought to be published had been stolen from the government. ${ }^{106}$ Despite the illicit means of acquisition, the Court held that the first amendment right to publish the information outweighed any alleged harm to the national security that would result from publication. ${ }^{107}$ Similarly, in United States $v$. Marchett $i^{108}$ the court recognized a first amendment right to disseminate imformation even though the dissemination violated a security agreement. ${ }^{109}$ It seems reasonably clear, then, that the existence of a first amendment right to disseminate information does not depend on how the information was acquired. ${ }^{10}$ It is logical, therefore, to extend

105. 403 U.S. 713 (1971).

106. The Court primarily addressed whether the harm posed to national security interests was sufficient to justify enjoining publication of the Pentagon Papers. Chief Justice Burger's dissent was quick to point out, however, that the papers were "purloined." 403 U.S. at 749 (Burger, C.J., dissenting). Moreover, Justice Harlan complained that the haste with which the courts dealt with the case resulted in a failure to address the question "[w] hether the newspapers are entitled to retain and use the documents notwithstanding the seemingly uncontested facts that the docunients ... were purloined from the Government's possession and that the newspapers received them with knowledge that they had been feloniously acquired." Id. at 754 (Harlan, J., dissenting). Sec also Comment, Discovery and the First Amendment, 21 WM. \& MARY L. Rev. 331, 337-38 (1979).

107. 403 U.S. at 714.

108. 466 F.2d 1309 (4th Cir.), cert. denied, 409 U.S. 1063 (1972).

109. Marchetti, upon resigning from the Central Intelligence Agency, signed a secrecy oath, promising not to disseminate "any information relating to the national defense and security" without prior consent from the agency. $466 \mathrm{~F} .2 \mathrm{~d}$ at 1312 n.2. The court refused to enforce this agrcement "to the extent that it purports to prevent disclosure of unclassified information, for, to that extent, the oath would be in contravention of his First Amendment rights." Id. at 1317. The court also concluded that Marchetti apparently had been given no consideration for the oath, "so that it would be, generally, unenforceable on that ground" as well. Id. at 1317 n.6. It is not clear on which ground the decision rests. The language concerning the first amendment, however, is persuasive authority for the proposition that a contractual agreement not to disseminate unclassified information is unenforceable. See also Snepp v. United States, 100 S. Ct. 763 (1980). In Snepp, the petitioner failed to submit a manuscript to the $\mathrm{ClA}$ for prepublication clearance, pursuant to an express agreement between the petitioner and the CIA. The Court, per curiam, held that the agreement created a fiduciary relationship between the parties. Snepp's breach of that relationship justified the imposition of a constructive trust in favor of the CIA upon the profits from publication of the manuscript. Notably, the United States did not ask the Court to restrain publication, nor did the Court consider such a remedy.

110. See Richmond Newspapers, Inc. v. Virgimia, 100 S. Ct. 2814, 2830 (1980) ("[This] Court has accorded virtually absolute protection to the dissemination of information or ideas") (Stevens, J., concurring); In re Halkin, 598 F.2d 176, 187 (D.C. Cir. 1979). The court in Rodgers v. Unitcd 
to the dissemination of discovery information a degree of first amendment protection at least equivalent to that accorded stolen information or information disseminated in breach of contract. ${ }^{111}$

\section{B. First Amendment Limitations on Restraining Extrajudicial Comment.}

A protective order prohibiting a party from disseminating discovery imformation operates as an infrimgement of that party's freedom of expression. Such a protective order should accordingly be examined in hight of the court's treatment of ordcrs restricting extrajudicial expression in analogous contexts. Only in rare cases has an order restraining extrajudicial comment by the press, the public, the parties, or the attorneys been upheld against a first amendment challenge.

The justification for an order restraming extrajudicial expression probably is strongcst in the criminal context, where the defendant has an explicit sixth amendinent right to a fair trial. ${ }^{12}$ In Nebraska Press Association v. Stuart, ${ }^{113}$ lowever, the Supreme Court held invalid an order restraining extrajudicial comments on a pending criminal case. The defendant was cliargcd with a brutal multiple slaying, and had been the subject of much prejudicial pretrial publicity. ${ }^{114}$ The Nebraska Supreme Court issued an order prohibiting the press from pubhishing or broadcastimg facts concerning any confessions made by the defendant or other facts "strongly implicative" of the defendant."15 Conceding that pretrial publicity might impair the defendant's right to a fair trial, ${ }^{116}$ the Supreme Court nevertheless invahidated the gag order and decided that all less intrusive alternatives must be exhausted before a court may impose a broad prior restraint. ${ }^{117}$ The Court suggested

States Steel Corp., 536 F.2d 1001 (3d Cir. 1976), also recognized a first amendment interest in dissemination of stolen materials. The Rodgers court, in refusing to issue a protective order prohibiting dissemination of information acqnired outside of the discovery process, noted that "[e]ven if, as respondents contend, [the imformation] were stolen, and we express no view on this, . . . that fact would not dictate a different result." 536 F.2d at 1008 n.16. See generally Cominent, supro note 106 , at $337-40$.

111. See note 86 supra; Comment, supra note 106 , at 336-40.

112. U.S. CONST. amend. VI.

113. 427 U.S. 539 (1976).

114. $I d$. at 542 .

115. State v. Simants, 194 Neb. 783, 801, 236 N.W.2d 794, 803 (1975).

I16. 427 U.S. at 562-63.

117. Id. at 563-65. See also Richmond Newspapers, Inc. v. Virginia, 100 S. Ct. 2814 (1980) (holding that the first amendment confers upon the press and the public a right to attend criminal trials). 
change of venue, postponement of trial, voir dire, jury instructions, and sequestration of jurors as potential alternatives. ${ }^{118}$

While the Nebraska Press Court did not explicitly discuss restraints on the extrajudicial cominents of lawyers, parties, or witnesses, ${ }^{119}$ the decision implies that gag orders are appropriate only where lesser alternatives will not suffice to protect a defendant's constitutional right to a fair trial. ${ }^{120}$ Even when orders that restrain extrajudicial statements are perinissible, they must be drawn as narrowly as possible under the circuinstances to ininimize the intrusion of the restrained party's first ainendment interests. To withstand first amendinent scrutiny, the trial judge must make a clear, specific finding that the order is necessary to prevent a substantial threat to the administration of justice. ${ }^{121}$

118. Id. at 563-64.

119. The Court's analysis centered upon the impact of the restraint on the press. The Court noted that in the earlier case of Sheppard v. Maxwell, 384 U.S. 333 (1966), it had outlined "other measures short of prior restraints on publication tending to blunt the impact of pretrial publicity." 427 U.S. at 564. In Sheppard the Court suggested that the trial judge "might well have proscribed extrajudicial statements by any lawyer, party, witness, or court official which divulged prejudicial matters." 384 U.S. at 361 . Justice Brennan's concurrence in Nebraska Press is instructive as well: "It is very doubtful that the court would not have the power to control release of information by [court personnel and attorneys] in appropriate cases." 427 U.S. at 601 n.27 (Brennan, J., concurring).

Recently, im Richmond Newspapers, Inc. v. Virginia, 100 S. Ct. 2814 (1980), the Court held that the press and the public have a first amendment right to attend criminal trials. In a plurality opinion, however, Chief Justice Burger carefully noted that the Court decided only:

whether a criminal trial . . . may be closed to the public upon the unopposed request of a defendant, without any demonstration that closure is required to protect the defendant's superior right to a fair trial, or that some other overriding consideration requires closure.

Id. at 2821 (opinion of Burger, C.J.). See also id. at 2829-30 (opinion of Burger, C.J.). The Richmond Newspapers Court, therefore, while conferring a constitutional right of access to courtroom proceedings recognized that in certain cases this right unay be outweighed by the defendant's right to a fair trial.

120. The power to restrain extrajudicial comment by attorneys, parties, or witnesses alluded to in Sheppard v. Maxwell, 384 U.S. 333, 361 (1966) (see note 119 supra), was undoubtedly offered in that case as a potential remedy for what had been a particularly massive prejudicial publicity campaign. See 384 U.S. at 338-49. Moreover, the Nebraska Press majority did not specifically refer to such restraints on extrajudicial expression as potential tools for protccting defendants, but only obliquely referred to Sheppard. See 427 U.S. at 564 \& n.8. Justice Brennan's concurrence in Nebraska Press would limit the availability of restraints on extrajudicial expression to "appropriate cases," which apparently are cases involving serious problems of prejudicial publicity. See id. at 601 \& n.27 (Brennan, J., concurring). See note 119 supra. Thus, a court should exhaust all alternatives short of restraint on expression before it restrains the extrajudicial expression of trial participants. Cf. Richmond Newspapers, Inc. v. Virginia, $100 \mathrm{~S}$. Ct. 2814 (1980) (absent suffciently compelling circuinstances, the press and public have a first amendment right to attend criminal trials).

121. See Chase v. Robson, 435 F.2d 1059 (7th Cir. 1970); $c f$. Nebraska Press Ass'n v. Stuart, 427 U.S. at 562-63 ("Our review of the pretrial record persuades us that the trial judge was justified in concluding that there would be intense and pervasive pretrial publicity concerning this case." Hence, the discussion of alternatives for minimizing the prejudicial effects of pretrial pub- 
Cases addressing the free-speech, fair-trial issue in the civil context closely track the criminal cases. ${ }^{122}$ In CBS, Inc. v. Young, ${ }^{123}$ a civil case arising out of the Kent State shootings in 1970, the trial court had issued a broad order restraining "all counsel and Court personnel, all parties concerned with this litigation, whether plaintiffs or defendants, their relatives, close friends, and associates [from] discussing in any manner whatsoever these cases with members of the news inedia or the public." 124 The Court of Appeals for the Sixth Circuit, relying heavily on an analogous crimmal case, ${ }^{125}$ held the order invalid; there was no substantial evidence of "serious and immment threats" 26 to the fairness of the trial, and the order was overbroad since it apphed to close friends, relatives, and associates, and prohibited discussion "in any inatter whatsoever." 127

In Chicago Council of Lawyers v. Bauer, ${ }^{128}$ the Court of Appeals for the Seventh Circuit invalidated Disciplinary Rule 7-107(G) of the American Bar Association Code of Professional Responsibility, which prohibited attorneys from making extrajudicial comments relating to evidence, witnesses, parties, the merits of a case, or any other matters reasonably likely to interfere with the fair trial of civil actions. ${ }^{129}$ The court noted that the right to a fair trial im a civil case sinply does not

licity, see text accompanying note 118 supra, was based on a substantial threat of sixth amendment deprivation).

The courts are split as to how much likelilood of harm must be demonstrated before an order restraining extrajudicial comment is justified. One series of decisions requires a "reasonable likeliliood" of a serious threat to a fair trial. See, e.g., Hirsclikop v. Snead, 594 F.2d 356, 370 (4th Cir. 1979); United States v. Tijerina, 412 F.2d 661, 666 (10th Cir.), cert. denied, 396 U.S. 990 (1969); Society of Professional Journalists v. Martin, 431 F. Supp. 1182, 1188 (D.S.C.), aff'd with qualifications, 556 F.2d 706 (4th Cir. 1977), cert. denied, 434 U.S. 1022 (1978). Another series employs a stricter standard-a "serious and imminent threat" to a fair trial. See, e.g., Chicago Council of Lawyers v. Bauer, 522 F.2d 242, 249 (7th Cir. 1975), cert. denied, 427 U.S. 912 (1976); In re Oliver, 452 F.2d 111, 114 (7th Cir. 1971); Chase v. Robson, 435 F.2d at 1061.

122. See generally Note, Gag Order Protection for Civil Trials, 64 Geo. L.J. 967 (1976).

123. 522 F.2d 234 (6th Cir. 1975).

124. $Y d$. at 236.

125. Chase v. Robson, 435 F.2d 1059 (7th Cir. 1970). Chase involved a criminal action for destruction of selective service files. The trial court ordered that all counsel and defendants refrain from making extrajudicial comments concerning the case. The court of appeals issued a writ of mandamus vacating the order because the trial court had failed to determine that the proscribed comments constituted a "serious and imminent threat to the administration of justice." Id. at $106 \mathrm{I}$.

126. 522 F.2d at 240 .

127. $I d$. at $239-40$.

128. 522 F.2d 242 (7th Cir. 1975), cert. denied, 427 U.S. 912 (1976).

129. The rule provides:

(G) A lawyer or law firm associated with a civil action shall not during its investigation or litigation make or participate in making an extrajudicial statement, other than 
enjoy the constitutional status of the sixth amendment right in a criminal case:

[A]lthough we rightfully place a prime value on providing a system of impartial justice to settle civil disputes, we require even a greater insularity against the possibility of interference with fairness in criminal cases. ... [M]ere invocation of the phrase "fair trial" does not as readily justify a restriction on speech when we are referring to civil trials. ${ }^{130}$

Moreover, the court explamed that, given the normal lengthiness of civil litigation and the legitimate use of civil suits to expose the need for government action or change, restrictions on extrajudicial comment in civil matters are especially suspect. ${ }^{131}$ Accordimgly, the court held that the areas of proscribed extrajudicial comment relating to civil matters einbodied in Disciplinary Rule 7-107(G) ${ }^{132}$ were "constitutionally impermissible if deened presunptively prohibited." 133

Judicial restraints on extrajudicial comment are thus permissible only in very narrow circumstances, even when the countervailing interest is the right to a fair trial. To survive constitutional scrutiny, an order must be drawn as narrowly as possible to minimize its intrusion on free speech. Restramts on the press and public are particularly disfavored in civil cases, where the fair trial right is not of constitutional proportions.

Protective orders prohibitimg dissemination of discovery materials are subject to similar scrutiny, as the Halkin decision demonstrates. ${ }^{134}$

a quotation from or reference to public records, that a reasonable person would expect to be disseminated by means of public communication and that relates to:

(1) Evidence regarding the occurrence or transaction involved. witness.

(2) The character, credibility, or crimimal record of a party, witness, or prospective

(3) The performance or results of any exammations or tests or the refusal or failure of a party to submit to such.

(4) His opinion as to the merits of the claims or defenses of a party, except as required by law or administrative rule.

(5) Any other matter reasonably likely to interfere with a fair trial of the action. ABA Code of Professional Responsibility, DR 7-107(G) (1975).

130. 522 F.2d at 257-58. See also Richmond Newspapers, Inc. v. Virginia, 100 S. Ct. 2814, 2829 n. 17 (1980) ("Whether the public has a [first amendment] right to attend trials of civil cases is a question not raised by this case, but we note that historically both civil and crimmal trials have been presumptively open.") (opinion of Burger, C.J.).

131. 522 F.2d at 258.

132. See note 129 supra.

133. $522 \mathrm{~F} .2 \mathrm{~d}$ at 258 . The court noted, however, that "[i]f some restriction is necessary in a particular case then perhaps a specific order can be entered supported by a record showing its necessity and the unavailability of a narrower restriction." Id. at 259.

The Fourth Circuit reached a similar result in the recent case of Hirschkop v. Snead, 594 F.2d 356 (4th Cir. 1979), in which the court invalidated DR 7-107(G) as overbroad and vague. "The dearth of evidence that lawyers' comments taint civil trials and the courts' ability to protect confidential information establish that the rule's restrictions on freedom of speech are not essential to fair civil trials. We thereforc conclude that this provision of the rule is invalid." 594 F.2d at 373 .

134. See text accompanying notes 90-91 supra. 
Although the considerations militating in favor of a protective order will usually not involve fair trial interests, but instead will focus upon the protection of confidentiality and the facilitation of the discovery process, the impact of such an order is the same as any order restraining parties froin making extrajudicial statements: freedoin of expression is circumscribed. Unless discovery merits soine special analysis under the first amendment, protective orders prohibiting dissemination of discovery mformation should be exammed with the same first amendinent scrutiny as other orders restricting extrajudicial coinment.

\section{Discovery, Protective Orders, and Unconstitutional Conditions.}

Access to discovery information is both created and regulated by the courts. ${ }^{135}$ Judge Wilkey's dissent in Halkin, ${ }^{136}$ the dictum in Rodgers, ${ }^{137}$ and the implications of Koons ${ }^{138}$ all suggest that the power to grant or deny access to discovery information necessarily imcludes the power to impose conditions on access; therefore, protective orders prohibiting dissemination do not merit strict first amendment scrutimy. ${ }^{139}$

As the Halkin court indicated, however, even though the discovery process is governed by the courts, a court may not condition access to discovery information on a waiver of constitutional rights. It is well settled that the government "may not deny a benefit to a person on a basis that infringes his constitutionally protected interests-especially, his interest in freedom of speech." 140 Permitting the government to

135. See text accompanying notes 11-17 supra.

136. See text accompanying note 93 supra.

137. See text accompanying note 53 supra.

138. See text accompanying notes $47-49$ supra.

139. Mr. Justice Holmes, sitting on the Supreme Judicial Court of Massachusetts, advanced a similar argument in McAuhffe v. Mayor of New Bedford, 155 Mass. 216, 220, 29 N.E. 517,517 (1892). The court in McAuliffe denied relief to a policeman who had been fired for violating a regulation that limited his right to engage in political activity. Justice Holmes' oft-quoted response to the policeman's claim was that "[t]lie petitioner may have a constitutional right to talk politics, but he has no constitutional right to be a policeman." Id. Justice Holmes went on to explaim:

There are few employments for hire in which the servant does not agree to suspend his constitutional right of free speech, as well as of idleness, by the inphed terms of his contract. The servant cannot complain, as he takes the employment on the terms which are offered him.

Id. at 220, 29 N.E. at 517-18. This view has been vigorously disputed. See generally L. TR1BE, AMERICAN CONSTITUTIONAL LAw $\$ 10-8$ (1978); Van Alstyne, The Demise of the Right-Privilege Distinction in Constitutional Law, 81 HARv. L. Rev. 1439 (1968).

140. Perry v. Sindermann, 408 U.S. 593, 597 (1972); accord, Pickering v. Board of Educ., 391 U.S. 563 (1968); Keyishian v. Board of Regents, 385 U.S. 589 (1967). See generally L. TRIBE, supra note 139, § 10-8; Van Alstyne, supra note 139. 
condition availability of a benefit upon the recipient's agreement to relinquish his constitutional rights "would allow the government to "produce a result which [it] could not command directly.".141

Literally applied, this doctrine of "unconstitutional conditions" seems to disallow any restrictions on constitutional rights that would be invalid if applied to persons not receiving government benefits. ${ }^{142}$ Applymg the doctrine in the discovery context, antidissemination protective orders miglit be permissible only if the same order would be valid as applied to independently acquired inforination. ${ }^{143}$ The doctrime has not been applied in this manner, however. Instead, governmental interests promptimg the attachment of a condition to a governmental benefit may make the condition permissible in certaim circumstances. ${ }^{144}$ The Supreme Court adopted this position in Pickering v. Board of Education, ${ }^{145}$ a case involvmg the dismissal of a teacher for criticizing scliool board policies. ${ }^{146}$ Altlougli the Court acknowledged that it is mipermissible to compel teachers to relinquish their first amendment riglits as a condition of employment, 147 it concluded that "the State has imterests as an employer im regulatimg the speecli of its employees that differ significantly from those it possesses in connection with regulation

141. Perry v. Sindermann, 408 U.S. 593, 597 (1972) (quoting Speiser v. Randall, 357 U.S. 513, 526 (1958)). "As a consequence, it seems to follow that the first amendment forbids the government to condition its largess upon the willingness of [a party] to surrender a right which he would otherwise be entitled to exercise . . . Van Alstyne, supra note 139, at 1446. See also Frost \& Frost Trucking Co. v. Railroad Comm'n, 271 U.S. 583, 593-94 (1926) ("If the state may compel the surrender of one constitutional right as a condition of its favor, it may, in like manner, compcl a surrender of all. It is inconceivable that guarantees embedded in the Constitution of the United States inay thus be manipulated out of existence").

142. See Van Alstyne, supra note 139, at 1448.

143. This is arguably the position taken by the inajority in Halkin. Judge Bazelon categorically refused to treat discovery information differently froin other information under the first aunendinent. See notes $82-86$ supra and accompanying text.

144. See Van Alstyne, supra note 139, at 1448 ("the connection with the government may in certain circuinstances make otherwise unreasonable conditions quite reasonable").

145. 391 U.S. 563 (1968).

146. The appellant was dismissed after writing and pubhishing in a newspaper a letter criticizing the board of education and the superintendent of schools for the manner im which funds were allocated between educational and athletic programs. The board conducted a hearing and found the stateinents to be false and unjustifiably disparaging. The appellant was dismissed because the letter was "detrimental to the efficient operation and adininistration of the schools of the district." Id. at 564.

147. The Court stated:

To the extent that the Illinois Supreme Court's opinion may be read to suggest that teachers may constitutionally be coinpelled to relinquish the First Amendment rights they would otherwise enjoy as citizens to comment on matters of public interest in connection with the operation of the public schools in which they work, it proceeds on a Id. at 568 . premise that has been unequivocally rejected in numerous prior decisions of this Court. 
of the speech of the citizenry in general."148 These countervailing governmental interests prompted the Court to fashion an ad hoc balancing test, weighing the teacher's free speech right to criticize the school board agamst the state's interest "in promoting the efficiency of the pubhic services it performs through its employees." 149 Using this balancing test, the Court found that dismissimg the teacher was improper because "the interest of the school administration in limiting teachers' opportunities to contribute to public debate [was] not significantly greater than its interest in limiting a similar contribution by any member of the general public," 150 and that interest was therefore insufficient to outweigh the teacher's first amendment interests. Thus, when the government provides a benefit to certain individuals, the constitutionality of any condition on access to that benefit-including a condition limiting the individual's constitutional rights-is determined by a balancing process in which the government's interests in imposing the condition are considered. ${ }^{151}$

Viewed in this light, protective orders prohibiting dissemination of discovery imformation, as a condition that limits the right of free speech, should be evaluated under a Pickering-type balancing test. Protective orders therefore deserve different first amendment treatment from orders restrictimg dissemmation of independently acquired information. Individuals who acquire mformation outside the discovery process have not received a government benefit that can be conditioned. Parties using the discovery process, on the other hand, should be subject to a test that weighs the restrained party's first amendment rights against the countervailing judicial interests of protecting litigants

148. Id.

149. Id. The Court's balancing test weighed a variety of factors. Those factors supporting a limitation of the first amendment right to free speech were the state's interest in removing incompetent employees, maintaining discipline, preserving morale, maintaining optimal working relationships, avoiding impairment of governmental operations, and rebutting false statements made by employees. The factors favoring the teacher's right to criticize were the individual's and the public's interest in free speech and the degree to which the speech concerned a matter of public interest. See id. at 569-74; Note, The Nonpartisan Freedom of Expression of Public Employees, 76 Mich. L. REv. 365, 368-69 (1977).

150. 391 U.S. at 573. The Court reasoned that the school cannot compel relinquishment of a teacher's first amendment rights any more than it can restrict the first amendment rights of other citizens, unless the school's legitimate countervailing interests in regulating its employees are sufficient. Since firing the teacher did not serve any legitimate countervailing interest, it had to be judged against the school's interest in regulating the expression of other citizens. There were no such interests; therefore, the disunissal was improper.

151. Id. at $568,572-73$. The balancing approach fashioned in Pickering was reaffirmed recently in Mt. Healthy City School Dist. Bd. of Educ. v: Doyle, 429 U.S. 274, 284 (1977), in which the Court declared, "[T]he question of whether speech of a government employee is constitutionally protected expression necessarily entails striking a 'balance' " between the teacher's free speech interest and the state's interest as an employer. See generally Note, supra note 149, at 375-402. 
and the discovery process by regulating dissemination of discovery information. When the balance tips in favor of protection, a protective order prohibitmg dissemination should be issued.

\section{Good Cause: A Workable Constitutional Standard}

\section{A. Interests in Prohibiting Dissemination of Discovery Information.}

A litigant may assert several legitimate interests in support of a protective order restricting dissemination of discovery information, including the right to a fair trial, ${ }^{152}$ protection of confidential information, ${ }^{153}$ and avoiding personal einbarrassment. ${ }^{154}$ In addition, the judicial system has interests of its own to protect. First, it has a strong interest in maximizing the effectiveness and efficiency of the discovery process. ${ }^{155}$ Liberal discovery has numerous important purposes, among them "to avoid surprise and the possible miscarriage of justice, to disclose fully the nature and scope of the controversy, to narrow, simplify, and frame the issues involved, and to enable a party to obtain the information needed to prepare for trial." 156 To insure that parties further these purposes by producing discoverable materials, it may be necessary for a court to issue an order restraining the dissemination of discovery materials. 157 Protective orders that restrict dissemination are a valuable discovery tool because they permit discovery while minimizing the adverse effect on the producing party. If such orders were unavailable, parties would be less willing to produce sensitive material, and judges would be more likely to issue protective orders denying discovery of sensitive inaterial. This result would hinder the discovery process unnecessarily. ${ }^{158}$

152. In re Halkin, 598 F.2d at $181-82$.

153. Rule 26(c)(7) expressly allows protection of "trade secrets or other confidential research, development, or commercial information." FED. R. CIV. P. 26(c)(7). Protective orders prohibiting dissemination are regularly issued in this context. See, e.g., General Dynamics Corp. v. Selb Mfg. Co., 481 F.2d 1204 (8th Cir. 1973), cert. denied, 414 U.S. 1162 (1974); Chesa Int'l, Ltd. v. Fashion Assoc., 425 F. Supp. 234 (S.D.N.Y.), affd, 573 F.2d 1288 (2d Cir. 1977); Vollert v. Summa Corp., 389 F. Supp. 1348 (D. Hawaii 1975); Xerox Corp. v. IBM, 64 F.R.D. 367 (S.D.N.Y. 1974); Essex Wire Corp. v. Eastern Elec. Sales Co., 48 F.R.D. 308 (E.D. Pa. 1969).

154. See, e.g., Nichols v. Philadelphia Tribune Co., 22 F.R.D. 89 (E.D. Pa. 1958).

155. The discovery process embodies the sound judicial policy that "prior to trial every party to a civil action is entitled to the disclosure of all relevant information in the possession of any person, unless the information is privileged." WRIGHT \& MILLER § 2001, at 15.

156. Id. $17-18$.

157. In re Halkin, 598 F.2d 176, 192 (D.C. Cir. 1979).

158. Id. Judge Bazelon explained that denying discovery altogether, rather than permitting discovery but restricting dissemination, "benefits no one, for in neither event will the public learn the contents of the discovery material, and when discovery is denied, the litigant will be deprived of information relevant to the preparation of the case." Id. at 195. 
Second, the courts have a substantial interest in minimizing the injuries suffered by parties as a result of participation in the discovery process. The courts have recognized, for example, that the first amendment does not preclude judicial remedies that prevent or redress injuries caused by dissemination of trade secrets, ${ }^{159}$ copyrighted material, ${ }^{160}$ or other information in which a party has a specific proprietary interest. 161 Similarly, when a party seeks to protect information that is truly confidential, the first amendment should not completely preclude restrictions on dissemination. ${ }^{162}$ Furthermore, discovery is unique im that it grants one party access to information held, often in confidence, by another party. An order compelling discovery, but not restricting dissemination, may operate to compel the producing party to make public information he seeks to keep private. Freedom of speech embodies "both the right to speak freely and the right to refrain from speaking at all." 163 In the absence of sufficient justification, a court's denial of a motion for a protective order may itself be an unconstitutional infringement of the producing party's first amendment rights. ${ }^{164}$ The courts should therefore give careful consideration to the producing party's request for protection from undesirable dissemmation. In particular, the right to disseminate discovery material increases the danger that the discovery process will be abused by parties to oppress their opponents unfairly. ${ }^{165}$ The courts should have the means to prevent

159. See, e.g., Federal Open Mkt. Comm. v. Merrill, 443 U.S. 340, 362 n.24 (1979), and cases cited therein. See also Notes of Advisory Committee, supra note 47, at 444.

160. See, e.g., Sid \& Marty Krofft Television Prods., Inc. v. McDonald's Corp., 562 F.2d 1157, 1169-72 (9th Cir. 1977) (defendant's argument that the first amendment operates to limit copyright protection was rejected by the court). The impact of the first amendment on copyright law, however, remains unclear. For enlightening discussions of this problem, see Denicola, Copyright and Free Speech: Constitutional Limitations on the Protection of Expression, 67 CAL1F. L. REv. 283 (1979); Nimmer, Does Copyright Abridge the First Amendment Guarantees of Free Speech and Press?, 17 U.C.L.A. L. REV. 1180 (1970).

161. See, e.g., Zacchini v. Scripps-Howard Broadcasting Co., 433 U.S. 562 (1977) (petitioner was not barred by the first amendment from recovering damages for alleged infringement of "right of publicity" regarding petitioner's human cannonball circus act). See generally L. TRIBE, supra note $139, \S \S 12-14$.

162. Cf. Cox Broadcasting Corp. v. Cohn, 420 U.S. 469,496 (1975) ("If there are privacy interests to be protected in judicial proceedings, the States must respond by means which avoid public documentation or other exposure of private information. Their political institutions must weigh the interests in privacy with the interests of the public to know and of the press to publish") (footnote omitted) (dictum).

163. Wooley v. Maynard, 430 U.S. 705,714 (1979).

164. See id. at 716-17; $c f$. Miami Herald Publishing Co. v. Tornillo, 418 U.S. 241, 256 (1974) ("Compelling editors or publishers to publish that which " "reason" tells them should not be published" "was held unconstitutional under the first amendment).

165. Professor Wright notes that:

Liberal discovery procedures are an important advance in the litigation process but it cannot be thought that they are an unmixed blessing. Any device, however salutory, 
such abuse. Protective orders that restrict dissemination serve this purpose well, without simultaneously interfering with the discovery process. ${ }^{166}$

To protect these interests, a court can fashion protective orders with great precision to minimize the restriction on expression. A motion to prevent the dissemination of specific discovery inaterial requires no speculation ${ }^{167}$ as to the nature or extent of the restraint on expression. The court inay examine the material in camera to determine specifically whether protection is necessary at all; if protection is necessary, the court can determine what information should be protected and what the nature of the protection should be. ${ }^{168}$ Accordingly, the inechanism for obtaming protective orders eliminates or at least minimizes many of the variables typically inherent im restramts on expression. A properly drawn protective order prohibiting dissemination of discovery inaterial would not be overbroad in its restraint on first amendment rights.

In short, the judicial system has substantial imterests in the continuing availability of antidissemination protective orders. These interests are unique to the discovery process; they are not present in other contexts where restrictions on extrajudicial comment are scrutinized under the first amendment. ${ }^{169}$ In assessing the validity of protective orders that restrict dissemination, these unique countervailing interests require that protective orders, unlike other judicial orders restraining extrajudicial expression, be subject to the balancing test proposed in Pickering $v$. Board of Education. ${ }^{170}$

The foregoing analysis refutes botli approaches taken in the case law concerning protective orders and the first annendment. On the one hand, parties plamly cannot be compelled to waive their first amendnient rights $\mathrm{m}$ order to participate in discovery, as Rodgers suggested. 171 That analysis runs afoul of the unconstitutional conditions

can be abused and there are undoubtedly instances in which a party will seek to use discovery in a way that will oppress his opponent. . . .

C. Wright, LAw of Federal CourTs $\$ 83$, at 412 (3d ed. 1976).

166. See text accompanying note 27 supra.

167. In re Halkin, 598 F.2d 176, 194 (D.C. Cir. 1979); cf. Nebraska Press Ass'n v. Stuart, 427 U.S. 539 (1976) (the impaet on a trial of potential pretrial publicity is necessarily speculative) Chicago Council of Lawyers v. Bauer, 522 F.2d 242, 251 (7th Cir. 1975), cert. denied, 427 U.S. 912 (1976) (per se restrictions on extrajudicial comment are unconstitutional: "these rules establish . . a blanket prohibition whereby even a trivial, totally innocuous statement could be a violation. The First Amendment does not allow this broad a sweep").

168. See, e.g., Kerr v. United States Dist. Court, 426 U.S. 394, 404-06 (1976). See also WRIGHT \& MiLLER $\$ 2035$, at 266 n.24.

169. See text accompanying notes 112-34 supra.

170. 391 U.S. 563 (1968). See notes 145-51 supra and accompanying text.

171. See text accompanying note 53 supra. 
doctrine. Judges do not have complete discretion to attach conditions on access to discovery information, as Judge Wilkey urged in his Halkin dissent. ${ }^{172}$ That a judge may deny discovery altogether is irrelevant. The governunent may likewise, in its discretion, deny employment. But the power to deny, in either context, does not include the power to attacli unconstitutional conditions. ${ }^{173}$ A court therefore may not exercise its discretionary power to prohibit dissemination without considering the first amendment implications of that action. ${ }^{174}$

On the other hand, Reliance and Halkin err in failing to differentiate between discovery materials and independently acquired information. ${ }^{175}$ Neither decision recognizes that the interests of the judicial system in a properly functioning discovery process may differ substantially from its interests im regulating extrajudicial coinment generally. ${ }^{176}$ These decisions are caught in what one commentator has termcd the basic flaw in the unconstitutional conditions doctrine: "the assumption that the same evil results from attaching certain conditions to government-connected activity as from imposing such conditions on persons not connected with government."177

Between these two approaches lies the correct position: the balancing approach of Pickering. The courts should recognize that the power to restrict dissemination of discovery material is indeed limited by first amendment considerations but that the countervailing interests in a properly functioning discovery process mandate a weighing of the competing concerns. Given the range of competing interests, it is not possible to fashion a precise standard for assessing the validity of protective orders restricting dissemination of discovery materials. The courts should balance the interests of the individual seeking protection and the interests of the judicial system against the first amendment rights of the parties to be restrained. As a consequence, the showing required to justify issuing a protective order will necessarily depend upon the particular circumstances of each case.

172. See text accompanying notes $93-96$ supra.

173. See Mt. Healthy City School Dist. Bd. of Educ. v. Doyle, 429 U.S. 274, 283-84 (1977).

174. Consequently, Judge Wilkey's logical admonition that the greater power of denial includes the lesser power to grant pursuant to conditions, see text accompanying note 96 supra, is incorrect. Though it may have intrinsic logical force, it carries little weight in constitutional analysis, where the impact of the condition, not the source of the power to apply it, is the critical factor.

175. Reliance failed to address the difference between discovery information and independently acquired information. Halkin expressly rejected the distinction: "We cannot agree with this bifurcated approach to the First Amendment's protection for speech." 598 F.2d at 186.

176. The judicial system's interests in a properly functioning discovery process are discussed at text accompanying notes 155-66 supra.

177. Van Alstyne, supra note 139, at 1448. 


\section{B. Incorporating the First Amendment into Good Cause.}

In re Halkin ${ }^{178}$ was the first case to set forth a constitutional standard for protective orders that restrict dissemination of discovery materials. The Halkin standard mandates that a protective order be issued only if the harm posed by dissemination is substantial and serious, the order is drawn narrowly and precisely, and there is no less intrusive means of affording protection. ${ }^{179}$ The Halkin dissent interpreted this standard as virtually reading out "any kind of a showing under Rule 26(c) as adequate support for a trial court's protective order." 180 A more hiberal construction of the Halkin standard is possible, however, and is fully consistent with the constitutional considerations outlined above. ${ }^{181}$ Such a construction fits nicely within the good cause requirement of rule $26(\mathrm{c})$, albeit incorporating a new first amendinent component into the good cause standard.

The first part of Halkin's three-part test requires that the harm posed by disseinination be "substantial and serious." 182 The court was unwilling to be more specific:

We decide today than an order restricting dissemination must be based on full assessment of the imterests at stake, with the party seeking the restraining order bearing the burden of making a concrete and specific showing of the likelihood of harm. ... We are reluctant at this time to fashion a hard and fast standard governing the requisite likelihood of harm which would justify all restrictive orders under Rule 26(c). Dissemination of different categories of discovery docuinents, in conjunction with different types of litigation, may well pose greater or lesser risks to the discovery process, and thus may require different treatment under Rule 26(c). ${ }^{183}$

Carefully weighing the factors inilitating for and against dissemination will not render protective orders unavailable. Rather, this consideration will cause judges to recognize that protective orders do, in fact, intrude on a party's broad first amendment interests, and that this intrusion should occur only when it is necessary. ${ }^{184}$ Read in this inanner,

178. 598 F.2d 176 (D.C. Cir. 1979).

179. Id. at $191-96$.

180. Id. at 211 (Wilkey, J., dissenting) (emphasis in original).

181. See text accompanying notes $135-51$ \& $155-68$ supra.

182. 598 F.2d at 191 .

183. Id. at 193 n. 42 .

184. In assessing the harm posed by dissemination, the court should, according to Halkin, take into account the variety of interests asserted in support of protective orders (such as national security, privilege, or trade secrets) and the need for a flexible tool to protect parties in discovery from abuse. When the asserted interest in support of a protective order is a fair trial, for example, two factors the court should consider are whether the trial is civil or criminal, see text accompanying note 130 supra, and whether the case is tried to the bench or to a jury (because presumably a 
the first Halkin factor is fully consistent with existing strict formulations of the good cause requirement of rule 26(c) mandating a showing of a "clearly defined and very serious injury." 185 The showing required under Halkin, however, expressly adds to "good cause" a requirement that the harin in dissemination be weighed against legitimate first amendment interests in dissemination. Merely alleging a "particular and specific demonstration of fact" 186 or merely showing that the noving party "will indeed be harmed by disclosure" 187 no longer justifies an order prohibiting dissemination. Thus, even though the required showing remains somewhat uncertain, the Halkin standard firms up the good cause standard by forcing the courts to recognize and consider the constitutional interests of the nonmoving party, instead of concentrating only on the interests of the party seeking protection. ${ }^{188}$

The second part of the Halkin standard, requiring that the protective order be narrowly drawn and precise, admonishes the courts to avoid overbreadth in restricting expression in any particular case. As Judge Bazelon noted in Halkin, courts easily can avoid issuing unnecessarily broad protective orders. ${ }^{189}$ Courts may examine information in camera to determine both the need for and the scope of protection. ${ }^{190}$ The constitutional requirement of narrow and precise orders is easily incorporated into good cause. Good cause should require more than a showing that protection is necessary; it should likewise require that the courts grant only necessary protection. As with the first Halkin factor, this requirement is a reasonable limitation on the discretion of the trial judge, making it necessary for the judge to consider carefully the scope of permissible protection in any given case. Again, the Halkin standard operates to define "good cause" more precisely, placing constitu-

jury may be more easily swayed by adverse publicity). $598 \mathrm{~F} .2 \mathrm{~d}$ at $192-93$. ln any event, the party requesting a protective order must present "a specific showing that dissemination of the discovery materials would pose a concrete threat to an important countervailing interest." Id. at 193 (footnote omitted). The Halkin court, however, did not decide how strong the threat of harm must be to justify issuance of a protective order. Id. at 193 n.42.

185. United States v. IBM, 67 F.R.D. 40, 46 (S.D.N.Y. 1975) (emphasis in original). See text accompanying notes 32-36 supra.

186. General Dynamics Corp. v. Selb Mfg. Co., 481 F.2d 1204, 1212 (8th Cir. 1973), cert. denied, 414 U.S. 1162 (1974). See text accompanying note 35 supra.

187. Johnson Foils, Inc. v. Huyck Corp., 61 F.R.D. 405,409 (N.D.N.Y. 1973). See text accompanying note 36 supra.

188. Cf. General Dynamics Corp. v. Selb Mfg. Co., 481 F.2d 1204 (8th Cir. 1973), cert. denied, 414 U.S. 1162 (1974) (courts should consider the general hardship on the nonmoving party in determining whether good cause exists).

189. $598 \mathrm{~F} .2 \mathrm{~d}$ at 194.

190. Id. Moreover, parties may, in appropriate circumstances, participate in these in camera proceedings, thereby avoiding the potential constitutional infirmities of ex parte orders. Id. at 194 n.43. 
tionally compelled outer limits on the discretion of the courts but at the same time permitting the courts to be flexible and imaginative in administering the discovery process.

The third part of the Halkin standard requires that protective orders restricting dissemination of discovery information be granted only in the absence of less intrusive alternatives. The availability of less intrusive alternatives will vary depending on the information sought to be protected and the reason for the protection. For instance, if, as in Halkin, the party seeking protection asserts that dissemination will interfere with the conduct of a fair trial, several alternative ways of msuring fairness-such as change of venue, postponement of trial, and sequestration of jurors-do not infringe on first amendment imterests. ${ }^{191}$ If a novimg party alleges that dissemination of confidential information will result in injury to business interests ${ }^{192}$ or personal reputation, 193 however, "[t]he only plausible alternative to a protective order may be the denial of discovery altogether."194 Although an order denying discovery avoids first amendment infringements and protects the confidentiality of the information, it also deprives a litigant of relevant and useful inforination that is otherwise discoverable. ${ }^{195}$ In such a situation, an antidissemination protective order is prefcrable over an order denying discovery.

A requirement that the court consider less intrusive alternatives before issumg a protective order that infringes on first amendment rights is perfectly compatible with rule 26(c)'s good cause standard, as are the other two parts of the Halkin test. Such a requirement merely makes the court consider all potential means of protecting litigants and choose the one that is least injurious to the affected parties. Incorporating the Halkin test into the good cause requirement of rule 26(c) transforms the good cause deterunmation into a balancing test that mandates close consideration of the facts and competing first amendment interests. The Halkin test does not unreasonably restrict either the availability of protective orders or the discretion of the courts in regulating discovery. The courts retain wide latitude in weighing one party's in-

191. Id. at 195. See Nebraska Press Ass'n v. Stuart, 427 U.S. 539, 563-64 (1976).

192. See, e.g., Essex Wire Corp v. Eastern Elec. Sales Co., 48 F.R.D. 308 (E.D. Pa. 1969) (antidissemmation order issued to protect confidential business information).

193. See, e.g., Nichols v. Philadelphia Tribune Co., 22 F.R.D. 89 (E.D. Pa. 1958) (antidissemimation order issued to protect personal reputation).

194. In re Halkin, 598 F.2d at 195.

195. See note 21 supra and accompanying text. Depriving the litigant of useful, discoverable information to protect the producing party is unnecessary and illogical. See text accounpanying note 158 supra. An order denying discovery altogether, therefore, has a more serious detrimental impact on the nonmoving party than an order permitting discovery but prohibiting dissemination. 
terests in requesting protection against the other party's first amendment interests in dissemination. 196

In summary, a sensible construction of the Halkin test allows for a Pickering-type balancing approach that protects constitutional freespeech interests adequately without inaking it impossible to obtain protective orders prohibiting dissemination. The Halkin test can be incorporated into the good cause requirement of rule 26(c). In the past, the courts have been unable to develop a workable standard of good cause for issuing protective orders prohibiting dissemination. ${ }^{197}$ In addition, the courts have not always considered the first amendment inplications of antidissemination protective orders. The Halkin test is an excellent formulation of the good cause standard that properly accounts for the constitutional right to disseminate discovery information. The test provides useful guidelines for assessing the interests of all relevant parties, for deternining the permissible scope of protection, and for deciding whether a protective order is actually necessary. At the same time, the Halkin test permits courts to use their sound discretion in deciding whether to issue protective orders.

\section{CONCLUSION}

The civil discovery process embodied in the Federal Rules grants litigants liberal access to information held by their opponents. Rule 26(c) empowers the courts to protect parties from being unnecessarily injured by this judicially created and adıninistered access system. Protective orders restricting dissemination of discovery information are a useful means of affording necessary protection in the proper circumstances. These orders, however, implicate first amendinent interests by restricting the expression of the party against whom they are issued.

Prior to In re Halkin, ${ }^{198}$ the courts that addressed the issue of the first amendment's impact on the availability of protective orders einployed conflicting and mconsistent approaches. The Halkin court correctly concluded that a party in litigation retains the first amendinent right to disseminate discovery information. The doctrime of unconstitutional conditions supports this conclusion; it indicates that the power of courts to deny discovery altogether does not immunize protective orders from first amendment scrutiny.

196. See Brink v. DaLesio, 82 F.R.D. 664, 677 (D. Mo. 1979) (“Although Judge Bazelon's criteria may have created a jurisprudential controversy, there is still a fair amount of judicial flexibility and freedom in determining the variables which must flesh out his approach").

197. See text accompanying notes 29-39 supra.

198. 598 F.2d 176 (D.C. Cir. 1979). 
Nevertheless, the interests of the judicial system in a reasonable and effective discovery system militate in favor of a balancing approach that permits protective orders prohibiting dissemination in appropriate circumstances. Liberally construed, the three-part test set forth in Halkin follows this kind of balancing approach. Read into rule 26(c)'s good cause requirement, the Halkin test provides for careful consideration of the first amendment interests that arise in the context of protective orders. At the same time, the Halkin test gives trial judges wide discretion to decide whether or not to issue these orders.

Few courts have yet looked to the Halkin case for guidance in determining whether there is good cause to issue a protective order prohibiting dissemination. Given the strength of the first annendment interest in dissemination, however, the courts should squarely confront the constitutional implications of granting protective orders. Properly interpreted, the Halkin test represents a useful set of guidelines for determining whether the need for a protective order outweighs the infringement of legitimate first amendment interests. Using the Halkin test to determine if good cause exists will doubtless render it inore difficult to obtain protective orders prohibiting dissemination than would a test that ignores first amendincnt concerns. But the good cause balancing test would not render these useful judicial tools coinpletely unavailable in regulating civil discovery. Instead, the valid interests of all parties, as well as the interests of the judicial system, would recieve proper consideration.

Donald J. Rendall, Jr. 